\title{
INVESTIGATIONS ON THE LEGITIMACY OF THE SWISS POLICE: ACTUAL DEBATES AND EMPIRICAL EVIDENCE ${ }^{1}$
}

Silvia Staubli

\begin{abstract}
Purpose - Actual debates around the Swiss police see a decrease in respect and an increase in attacks towards police officers. Such non-respect can be seen as a lack of feelings of obligation to obey to the police. Instead of asking whether such a proclaimed increase in disrespect is indeed happening in Switzerland, this chapter analyses aspects of legitimacy. It builds on the question whether the population sees the Swiss police as a legitimate force.

Methodology/Approach - Swiss police's legitimacy will be elaborated in two parts. After giving an overview about current debates, known theoretical aspects of legitimacy will be outlined. These aspects build the ground for empirical analyses that follow. Results are based on data of the European Social Survey ESS5.

Findings - The Swiss population sees the police as a legitimate force. The majority are morally align with the police, they feel an obligation to obey to their directives, and they ascribe legality to their actions. Furthermore, also procedural fairness is highly ascribed to the Swiss police. Finally, age correlates only with certain aspects of legitimacy. While moral alignment increases with age, as well as positive views about police's procedural fairness, no effects were found for feelings of obligation to obey. However, elderly people more often see a political influence on police's decisions and actions.

Originality/Value - While in Anglo-Saxon countries research on legitimacy of the police is broad, no analyses are known for Switzerland so far. Moreover, topics around the Swiss police are often emotionally debated in media, whit a lack of empirical evidence. This chapter contributes to close this gap. It gives an insight on the population's perception of the Swiss police and offers an important scientific foundation for actual debates.
\end{abstract}

Keywords: Legitimacy; trust; police; Switzerland

\section{INTRODUCTION}

Topics of inadequate and prejudiced behavior of police officers are prominent in research and the media. Especially reports about ethnical discrimination and maltreatment by police officers in the United States became more common. However, in Switzerland, debates rather deal with a decrease in respect and an increase in attacks towards police officers. Independently of the question whether or not such an increase in attacks in Switzerland is

\footnotetext{
1 Author Accepted Manuscript (AAM)

Citation: Staubli, Silvia (2016). Investigations on the Legitimacy of the Swiss Police: Actual Debates and Empirical Evidence. In: Deflem, Mathieu (ed.). The Politics of Policing: Between Force and Legitimacy (Sociology of Crime, Law, and Deviance, Volume 21, 97-114). Bingley, UK: Emerald ISSN: 1521-6136 doi:10.1108/S1521-613620160000021006
} 
given, in order to understand such behavior, it need to be clarified why people obey to the police. Moreover, it must be asked what constitutes legitimacy of the police. Therefore, the core question of this paper is whether the Swiss police are seen as a legitimate force.

I will begin with an outline of actual debates around the Swiss police, describing shortly a riot that happened at the end of the year 2014 in Zurich. After that, I will clarify different theoretical aspects of legitimacy such as obligation to obey, moral alignment, legality of action, or procedural fairness. In the chapter that follows, I will present some results about Swiss police's legitimacy, based on views of the population. Analyses are mainly based on data of the European Social Survey ESS round 5 of the years 2010 and 2011. Results reveal that the Swiss population ascribes high levels of legitimacy to the police. However, in the discussion section, I will outlie why such results must be treated with caution and what other aspects need to be considered when talking about Swiss police's legitimacy.

\section{BACKGROUND}

\section{Actual Debates around the Swiss Police}

Since the end of the year 2014, news coverage about shootings and other maltreatment of Afro-Americans by American police officers spread around the world. As a reaction, the police was criticized and demonstrations not only by colored people accusing racism within the police were organized. Moreover, large debates about racism within the culture and in the daily life were started. However, in Switzerland, the topic of racism by the police only seldom appears in media. In addition, it can be said-even though there is no official data to proof this statement-happens rather seldom. Besides racism, also another topic debated in international media does not affect Switzerland: shootings of unarmed people. The statistic of use of firearms shows that in 2014, police officers used their firearm only in 11 cases (Tages Anzeiger, 2015). However, at the same time, a steady increase in use of electroshock weapons can be reported (Schmid, 2015). While in some police corps every foot patrol is equipped by such a weapon, in others only specialized police officers are allow to wear one.

Inadequate operations and tactics by the police are debated, though, especially when happening at a local context around demonstrations, for example. Not least because the population and the media watch police officers and their behavior very carefully, misconduct is criticized and-most of the time-unveiled. While the police react very sensitive to criticism made by the public, at the same time, they care a lot about other people's opinion (Van Maanen, 2003). That the public watches carefully how the police work on the street is nothing new. However, since the 1990s, a diversification in media formats lead to the fact that the police are not only observed by bystanders, but also filmed (Meyer, 2012a). Mobile phones are equipped with good cameras, and especially young people are used to film and to distribute such films rapidly amongst their colleagues and friends. However, often, such films only give a shortened version of what really happened. That is why police officers widely belief that media mainly report negatively about their work, and that their actual practices are hardly visible (Meyer, 2012b).

Another topic around the police that was debated more widely during the last years in Switzerland was a decrease in respect, and, in accordance with it, an increase in attacks towards officers. In 2009, the Association of Swiss Police Officers (VSPB) passed a petition 
for the attention of the Federal Council and the Federal Parliament. They claimed an increase of violence against police officers, which in their view is an act against their employer, the state. Consequently, they requested the following adaptations in the Swiss Criminal Code: a reintroduction of short sentences; a raise of the minimum penalty for violence and threat against officers and authorities (Art. 285 of the Swiss Penal Code (StGB)); and, finally, in case of reoffending, that penalties should be doubled and an imprisonment should be unavoidable $^{1}$. Two years later, in 2011, the VSPB launched the awareness campaign Stopp der Gewalt gegen Polizisten/innen (stop of violence against police officers). Additionally, in order to maintain the debate, the VSPB documents the worst cases of attacks towards police officers on their website.

In the following years, the topic was less prominent in media, but discussions started again on December 12, 2014. At this day, heavy riots in Zurich, done by a relatively small group of people, left not only the public perplex behind. The group marched towards the Longstreet, crossing a new area with recently built modern houses, shops and cafes, called the Europaallee. They sprayed slogans such as "fuck the police" on walls, destroyed windows and left this newly built area in a short time devastated behind. As the group organized themselves relative spontaneously via text messages, the police were taken by surprise. After arriving on the scene, the mob acted aggressively and attacked the police violently. The public and the media were left behind perplex, as at the beginning the reasons for the riots remained unclear. Passionate discussions about who might be responsible were going on. While some news media journalists saw a bunch of anarchistic juveniles of the black block as the dominators of the riots, others reported about hooligans or members of the squatting scene as being responsible. Only about three weeks later, the organization "reclaim the street" published a letter of confession, criticizing restructuring processes in the "city of rich people", which leads to displacements of poorer people to outskirts (contrainfo, 2015).

Such a riot without a link to an event such as a football derby or a political demonstration was new for Switzerland, at least for its largest city Zurich. Criticisms and incomprehension dominated media reports. Even people with generally critical opinions towards the police from the left side of the political spectrum raised their voice and criticized the destructions. One reason was that not only buildings at the Europaallee were destroyed, but also smaller shops around the Longstreet, an area known for its multiculturalism and creativity. Additionally, police officers were faced with heavy violence. Many people argued that the concerns being raised by the demonstrators were justifiable, but that they crossed the red line when applying heavy violence, taking into account severe wounded police officers. While such events happen rarely, disrespect and attacks towards police officers in their daily work are more common. One focal point is the nightlife, where alcohol consumption affects selfcontrol, what leads to disobedience and non-compliance of laws (Gyr, 2013). Especially young people were accused to lose respect in such situations. Research has shown that age matters when it comes to views about and encounters with the police (e.g. Reisig and Correira, 1997; Skogan, 2005; Bradford, Jackson, and Stanko, 2009; Wu and Sun, 2009; Gau, 2010; Jackson et al. 2012a; Staubli, 2015). For Switzerland, data of violence and threat against public authorities and officials, which is part of the Swiss criminal statistic, supports an assumption that mainly young people are responsible for tendencies of lower respect and 
increasing attacks towards police officers. Analyses show that the total number of attacks decreased since 2012. Additionally, the amount of registered people younger than 20 years steadily decreased over the years between 2009 and 2014. Contrary to this, a clear increase can be reported for 30- to 34-year-olds, while numbers for the 25- to 30-year-olds also increased over this time, but less clearly. Considering data of the year 2014 only, it can be seen that about every third case of such offenders registered by the police falls in the age group of 18 - to 25 -year-olds. Moreover, the age span of 18 to 34 years covers more than $63 \%$ of the cases. These numbers suggest that age is an important factor when it comes to attacks towards the Swiss police. Hence, this statistic often builds the basis for statements about increasing attacks towards police officer. However, it is marked by a severe weakness: it includes not only attacks towards police officers, but violence and threat against all public authorities and officials. Even though this data shows that attacks towards public officials in fact increased, numbers say nothing about the group of police officers alone. It might be that such an increase is mainly caused by attacks towards another group of officials such as paramedics.

Reports about disrespect and attacks towards police officer lead to the assumption that the population, or at least certain subgroups, do not ascribe legitimacy to the Swiss police anymore. This chapter builds on this aspect by asking whether or not the population sees the Swiss police as legitimate and whether age does matter. Before presenting some empirical results, in the next chapter, I will elaborate on the question what constitutes legitimacy.

\section{Conceptual Issues}

Media reports but also the Association of Swiss Police Officers themselves claim that disrespect and attacks towards police officers have increased. This leads to the question why people comply with institutional representatives and orders given by them. One important aspect is legitimacy. According to Weber (1980), legitimacy of an order can be guaranteed internally through values, or externally trough the expectation of consequences. Furthermore, there are several aspects how those acting within such an order ascribe legitimacy to this order. Weber mentions belief, either in an emotional or rational form, amongst others. It can be followed, that not only people's belief in police's legitimacy needs to be considered. In addition, the question of how this legitimacy can be justified must be faced. Sunshine and Tyler (2003, p. 514) see legitimacy given when an authority or institution has a property "that makes people feel that that authority or institution is entitled to be deferred to and obeyed". Such a "property" that will lead to legitimacy can be legality-whether the police exercise their power within the law,--and action (Beetham, 1991; Weber, 1980). A fair and respectful treatment of others can be seen as a convention of our society, for example. Hence, when the police apply this convention to their work on the street, they will gain legitimacy through action. In addition, institutions are also seen as legitimate when there is a feeling of shared values, when people feel morally align with the police (Hough et al., 2010). When the population feels that the police represent normative values similar to their own, they will trust that the police will use their power adequately (Hardin, 2002). Moreover, they will see them as legitimate to do their job, which might include use of force in certain situations. Feelings of obligation to obey to and a moral alignment with the police are associated with feelings of 
satisfaction with the police and hence their legitimacy (Reisig and Chandek, 2001; Tyler and Huo, 2002).

It can be followed, that people who view the police as a legitimate authority will obey police officers as they are trusted as acting fairly (Tyler and Huo, 2002). By contrast, people not showing respect towards police officers and attacking them violently might deny legitimacy to the police. In addition, there are two other possible explanations for such a disobedience. Firstly, such individuals, for example the protesters of the riots mentioned above, might not be afraid of consequences law wise. Hence, deterrence effects based on laws as postulated by instrumental approaches might not be effective enough or not adequate anymore. Even though such approaches are meant for general law breaking such as thefts or misuse of substances, I argue that they can also be enlarged to specific situations of police encounters. Not at least Swiss police officers often feel abandoned by the courts and the law in general after attacks towards them. They complain that courts often do not punish the aggressors adequately (Raval, 2015). Yet, the frame of this book chapter does not allow investigating on the question whether this is true or not. However, empirical analyses of items measuring the strength of concerns of being caught after breaking a law will give information about how people evaluate deterrence effects of Swiss laws in general.

Secondly, compliant behavior can be based on normative values and social relations (Tyler, 2006). The set of values based on internalized obligations of people not following rules and regulations of police officers might be different from those people encounter with the police respectfully. Tyler (2006) proposes two types of internalized obligations. The first one addresses authority: legal authorities are seen as having a legitimate right to dictate a behavior. Contrary to this, the second aspect is settled at the individual level: people behave in ways that fulfill their internalized obligations concerning an adequate, moral behavior. A core element of moral values is that people feel a personal responsibility to follow such values. Consequently, they will feel guilty when failing to do so (Tyler, 2009). Personal morality was also proven an important attribute when it comes to compliance with the law (e.g. Jackson et al. 2012b).

It can be followed that, when an authority such as the police are seen as legitimate, people would comply even when they disagree with a directive, based on a feeling of obligation to obey. They trust in the police that they have the right intentions towards citizens and have the competence to act effectively (Tyler, 1998). Recent studies have doubted that such feelings are "truly free consent" (Tankebe, 2013). Contrary to this, a negative connotation might also be possible, out of a feeling of having no other choice than to obey to the police. However, Jackson et al. (2015), pursuing this thought, did not found any support for a coercive obligation in their analyses.

Another approach focuses on processes. In encounters with the police, both fair processes and fair outcomes lead to trust in and cooperation with the police. However, processes seem to outweigh outcomes (Tyler and Huo, 2002; Hough et al., 2010; Tankebe, 2013). Such a process-based policing contributes to people's cooperation with the police and their acceptance of decisions done by police officers. Moreover, it reduces the risk of an aggressive behavior of individuals (Tyler and Huo, 2002). When people feel that they were treated fairly in an encounter with the police-Tyler (2006) mentions aspects such as neutrality, lack of bias, 
honesty, efforts to be fair, politeness, and respect for citizens' rights-, they will attest legitimacy to the police. According to the normative perspective, such factors are more important than instrumental ones, for example whether the outcome was favorable or not. The art of treatment in police encounters was proven being important for views about the police. Whether people are satisfied with an encounter with the police, whether they were treated fairly and respectfully, has a strong influence on people's trust in the police and their view about police's legitimacy (Sunshine and Tyler, 2003; Tyler, 2006; Staubli, 2015).

Reports in Swiss news media describe a picture of a decrease in respect towards officials, leading to an increase in attacks towards the police. Besides, riots such as those in Zurich are situations with a strong potential of violence. Concrete and spontaneous aggression and violence towards the police often arises in conflictive situations, such as during demonstrations or before/after football matches. This implies that certain subcultural groups more often deny legitimacy to the police. Research has shown that groups with a shared social identity who see it as being similar to those of police officers more easily establish social bonds and a moral connection with them (Bradford, 2014). Such a shared social identity can be the belonging to the same nation, ethnical minority or community and builds the basis for trust in the police (Jackson and Bradford, 2010). However, it might also work the other way round. Feelings of different social identities between social groups and police officers might lead to mistrust. Besides social identity, a general suspiciousness, defined as a low social trust towards unknown others, is linked to a lower trust in the police (Staubli, 2015).

Not only social identity was found as one aspect affecting views about the police and their legitimacy, but also age. Research has shown that young people trust the police less. However, they are also more often involved in police encounters known to be important in shaping police's trustworthiness (Reisig and Correira, 1997; Skogan, 2005; Bradford, Jackson, and Stanko, 2009; Jackson et al. 2012a; Staubli, 2015). Nevertheless, age will be considered when doing empirical analyses on Swiss police's legitimacy further below.

Based on the elaborations above, it can be followed that several factors need to be considered when doing research on Swiss police's legitimacy. Firstly, legitimacy can be measured according to feelings of obligation to obey and moral alignment. Secondly, views on police corruption and their legality of actions need to be considered. In addition, factors of procedural fairness were proven as being important for shaping views on the legitimacy of the police. Moreover, when considering obedience with the police, risk of sanction as well as personal morality need to be taken into account. Finally, deterrent effects play a role as well.

\section{EMPIRICAL EVIDENCE}

\section{The Swiss Police are seen as a Legitimate Force}

When it comes to institutional trust, yearly opinion polls show that trust in the Swiss police is high, with more than $70 \%$ of the population trusting them. Moreover, amongst Swiss institutions, the police are trusted the most, followed by the courts and the Swiss Federal Council. Finally, political parties and the media are least trusted (Szvircsev Tresch and Wenger, 2015). These high levels of institutional trust contrast with the claimed decrease of respect and the (perceived) increase of attacks towards police officer. Besides this mentioned data, in contrast to other countries with a long tradition in police research, the data situation is 
poor in Switzerland. There are especially no larger national databases. However, the core module of the fifth round of the European Social Survey (ESS5), with questions around procedural fairness and legitimacy of justice, allows getting a first insight on police legitimacy. Data for Switzerland was collected in the years 2010 and 2011, with a sample of 1'506 individuals. Perceived legitimacy of the police was measured according to three item batteries: obligation to obey, moral alignment, and corruption and legality of action. Obligation to obey was measured according to the following questions: To what extent is it your duty to ...back the decisions made by the police even when you disagree with them? ...do what the police tell you even if you don't understand or agree with the reasons? ...do what the police tell you to do, even if you don't like how they treat you? Moral alignment was covered by the answers to the following statements: The police generally have the same sense of right and wrong as I do; the police stand up for values that are important to people like me; I generally support how the police usually act. In addition, the following two aspects covered legality of action: The decisions and actions of the police are unduly influenced by pressure from political parties and politicians; how often would you say that the police in [country] take bribes? Furthermore, procedural fairness (How often do police treat people in country with respect? How often do police make fair, impartial decisions? How often do the police explain their decisions and actions when asked?), and statements about laws in general (all laws should be strictly obeyed; doing the right thing sometimes means breaking the law) were included in analyses. Deterrence was measured according to items of risk of sanctions (how likely it is that you would be caught and punished if you... made an exaggerated or false insurance claim, ...bought something you thought might be stolen, ...committed a traffic offence like speeding or crossing a red light). Finally, in order to have information about one's personal morality, it was asked how wrong it would be to commit one of the offences stated before. For further details of questions, see European Social Survey ESS5 (2010).

Result show that citizens of Switzerland generally accept the police as a legitimate force. The majority of people feel an obligation to obey to the police: $46.1 \%$ show high feelings of an obligation to obey, $39.7 \%$ middle, and only $10.6 \%$ report low feelings of obligation to obey (trichotomy based on a ten-point scale). Furthermore, Swiss people are also morally align with the police: $77.3 \%$ generally support how the police act, $71.2 \%$ think that the police have the same sense of right and wrong as they have, and finally, $80.8 \%$ agree that the police stand up for values that are important to people like them. Percentages for opinions on obedience are high as well, with only $11 \%$ of the population reporting low feelings of obligation to obey. Moreover, $55.4 \%$ do not see the police as influenced by politics. Finally, $74.3 \%$ report that the police in Switzerland do not take bribes, $23.2 \%$ sometimes, and only $2.5 \%$ often (trichotomy based on a ten-point scale). In addition, the Swiss police are highly seen as procedurally fair: $87.5 \%$ report that the police treat people with respect, $82.8 \%$ that the police make fair and impartial decisions and, finally, $75.5 \%$ that the police explain their decisions and actions when asked. Interestingly, only $1.1 \%$ report that no one ever asks the police to explain their decision. It can be followed that it is common in Switzerland to ask the police how they came to a certain outcome such as a fine or why they acted in a specific way. This can be seen as a hint towards the Swiss culture, which is rather marked by equality than by hierarchy where 
authorities need to be respected. Moreover, this would support police officers' complaints that the police are not respected anymore as a higher authority one has to obey.

When it comes to deterrence, the estimation of risks of sanction of being caught when committing an offence differs. While $75.5 \%$ of people report that it is likely that they will be caught after committing a traffic offence, only $60.1 \%$ see such a chance after making an exaggerated or false insurance claim. Finally, less than every second (46.9\%) does evaluate the risk of a sanction being likely for buying something that might be stolen. Such views about how likely someone might be caught are closely linked to one's personal morality. While $31.4 \%$ do not evaluate a traffic offence as being morally very wrong, around $87 \%$ argue that making an exaggerated or false insurance claim or buying something that might be stolen as being against morality. When it comes to laws in general, the large part of the Swiss population $(73.2 \%)$ argues that all laws should be strictly obeyed. Contrary to that, fully $57.5 \%$ see sometimes a necessity to break the law in order to do the right thing.

It rest the question how the mentioned items of legitimacy, procedural fairness and deterrence are correlated. Table 1 shows that all four items measuring perceived legitimacy of the police-moral alignment, obligation to obey and corruption and legality of action-correlate statistically significantly with each other. Strongest coefficients can be reported for perceived police corruption: the more people believe that the Swiss police take bribes, the less they feel morally align with the police and the less they feel an obligation to obey to them (or vice versa). Additionally, they perceive that the decision and actions by the police are influenced by political pressure. Corruption in Switzerland is generally low (Transparency International, 2014). Hence, people who evaluate the police as being corrupt might have a general suspiciousness towards the institution as a whole. What became visible too is the strong effect of procedural fairness. People who ascribe fairness to the Swiss police, strongly feel morally align with them $(r=.474)$. Even though the correlation is less strong with feelings of obligation to obey, it is statistically highly significant $(r=.106)$. Furthermore, moral alignment goes along with personal morality $(r=.176)$, while the correlation with obligation to obey remains meaningless and non-significant $(r=.018)$. Personal morality is also statistically significantly related to risk of sanctions ( $r=.159)$ and age $(r=.241)$. Results confirm that deterrent effects of being caught for traffic offences or others are not coupled with views about police's legitimacy. While the risk of a sanction when doing something illegal has no effect on views about police's legitimacy, statements about compliance with the law in general are better indicators. Correlation coefficients are strong for people who state that laws in general need to be obeyed strictly and moral alignment ( $p=.251)$, as well as with obligation to obey to the police $(p=.175)$. Moreover, this statement correlates positively with procedural fairness $(p=.203)$ and personal morality $(p=.218)$, but also with risk of sanctions $(p=.098)$. In line with that is that the statement doing the right thing sometimes means breaking the law correlates negatively with moral alignment ( $p=-.128)$, obligation to obey ( $p=-.146)$ and procedural fairness ( $p=-.163$ ). Contrary to that, positive correlations are found with views about police's legality of action. People who report that the police take bribes and that their decisions and actions are influenced by political pressure, more often view the law as breakable in certain situations, or, of course, vice versa $(p=.166, p=.129)$. 
Concerning age, it can be seen that it correlates positively with moral alignment ( $p=.157)$. Interestingly, the correlation with obligation to obey is negative ( $r=-.054)$. However, the coefficient is low and non-significant.

\section{Table 1 about here}

Young People as Main Aggressor?

When differing the two main ESS5 items for legitimacy according to age, study results showing an age factor can only partly be confirmed. Results reveal that moral alignment with the police increases with age $(\mathrm{p}<0.001)$. Of the 14 - to 25 -year-olds, $66 \%$ agree with the three statements about moral alignment, slightly more of those up to 40 years $(67.3 \%)$. A clear increase can be reported for those older than 60 years, with $83 \%$ being morally align with the police.

Results for feelings of obligation show a tendency that obedience decreases with age: while around $78 \%$ of those people younger than 40 years report that they feel a duty to obey to the police, it is $76.7 \%$ of the 40 - to 50 -year-olds and only $71 \%$ of those older than 60 years. Moreover, the same pattern as for percentages of moral alignment can be reported here, with similar numbers up to 40 years and a change only with a higher age. However, correlations do not meet statistical significance, and percentages shown are based on a dichotomization of the ten-point scale, which simplifies the picture given.

Concerning views about police's legality of action, it can be reported that more elderly people see an influence of political pressure than representatives of younger age groups do ( $\mathrm{p}<0.01$ ). While $42.7 \%$ of the 14 - to 25 -year-olds see the police influenced by politics, it is around $52 \%$ of those aged between 26 to 39 years and 40 to 59 years. People elderly than 60 years slightly more often agree with the statement $(54.3 \%)$. When it comes to bribes, only small amounts of Swiss people believe that the police are corrupt. Those $10 \%$ are more or less evenly distributed across the age groups, with slightly less agreement amongst elderly people ( $p<0.1$ ): $14-24$ years: $11.9 \%, 25-39$ years: $14 \%$, $40-59$ years: $9.1 \%$, over 60 years: $7.9 \%$.

Age does matter when it comes to the evaluation of police's procedural fairness. Results show that the younger the age group, the less often procedural fairness is ascribed to the police. Nevertheless, as the police are overall seen as acting fairly when it comes to their procedures and decisions, differences rank at a high level with $82.7 \%$ agreement amongst the youngest age group and $90.4 \%$ amongst those older than 60 years.

\section{DISCUSSION}

Theoretical approaches outline legitimacy as based on several aspects. When people feel obliged to obey to an authority and when they feel morally align with them, they will ascribe legitimacy to them. The police are viewed as a legitimate institution when people feel a duty to do what the police say and to back their decisions, even when they do not agree. Moreover, when people support how the police act and when they feel that they share the same values, they also view the police as legitimate. Items of the ESS5 are based on such theoretical 
aspects. Results confirm that the majority in Switzerland view the police as a legitimate force. However, when discussing the results found, one must be aware of structural influences. In contrast to countries with a total centralization of the police such as Sweden (Brodeur, 2008), Switzerland is marked by decentralization. Each canton has its own forces and its own police law. Hence, there is no "Swiss police". Predecessor of the current cantonal police forces were already built in 1805 based on the so-called Mediationsakte of Napoleon, where the creation of cantonal police forces was decided and written down (Schmoll, 2009). Also today, cantons and communes are responsible for enforcing security, even though police structures follow the federal political structures. However, such demarcations are not very meaningful anymore. That is why alliances between corps became common. Community polices are bind together with regional polices, and the cantonal police forces organize themselves in police concordats (Jeker, 2005). Even though such concordats such as the Conference of the Cantonal Police Commanders (KKPKS) aim to find joint strategies and a uniform police doctrine, decisions made at the request of the management board have the characteristic of guidelines and suggestions and are not legally binding. Hence, even though cooperation at the national level is envisaged, corps differs widely in how they apply strategies such as community policing or problem-oriented policing, amongst others (Bänziger, 2014). Moreover, there are tensions and competitions between police forces that hinder joint strategies. One hindrance of getting suitable aspirants is the increased visibility of the police in media, which exerts pressure on them being more efficient (Meyer, 2012b).

It must also be noted that empirical results presented above have several limitations. Firstly, they are based on views of the Swiss population as a whole. Even though the police can be claimed as a legitimate institution in Switzerland that will be obeyed, there seem to be certain groups of people not accepting them as an authority. One statistic often used sees younger people more often responsible for violence and threat against public officials. However, this data does not allow drawing conclusions for the police alone. Results based on the ESS5 show that certain aspect of legitimacy such as moral alignment increase with age. Contrary to that, no strong age differences were found for feelings of obligation to obey to the police. Research also showed that social identity is an important aspect when it comes to identification with police officers (e.g. Bradford, 2014). In Switzerland, contrary to other countries such as in France, there is no advanced spatial segregation of ethnical minorities in certain quartiers of larger cities. Therefore, I would say this is a less prominent source of conflicts with and disrespect towards the police. What appears to be more important are subgroups such as those responsible for the riots in Zurich. Unfortunately, data used for this chapter does not allow investigating on them. Such groups are difficult to reach and will hardly participate in a survey. Furthermore, local aspects need to be considered. Disobedience by a drunken juvenile at Saturday night in a nightlife district has other sources than a spit attack of a middle-aged man at daytime during a check of personal data. In-depth analyses of data of all attacks towards police officers in Switzerland could help shedding light on the circumstances. This, however, would require access to such sensitive data, which eventually would also bring to light inadequate behavior by the police themselves. Finally, descriptive results as given in this chapter only give a first insight into the topic. In order to get a broader perspective, complex empirical analyses such as structural equation models are needed. 


\section{CONCLUSION}

The aim of this paper was to clarify whether or not the Swiss population sees the police as a legitimate force. Moreover, it was asked whether people obey to the police and what the origin of such obedience might be. The investigation on police's legitimacy was based on debates in the media about an increase of attacks towards police officers, and on riots in Zurich. Elaborations on theoretical aspects of legitimacy built the basis for empirical analyses.

Descriptive results based on the ESS5 show that the majority of the Swiss population have strong feelings of obedience towards the police. In addition, they have shared moral values and do not doubt largely the legality of actions by the police. Furthermore, procedures used by the police are overall evaluated as being fair. While the majority of the Swiss population feels obliged to obey to laws in general, a relative large part accepts a violence of laws in certain situations.

Outlined results about Swiss police's legitimacy revealed that despite a possible decrease in respect towards police officers, the institution police is still trusted and its legitimacy is undoubted. However, some questions remain open. It might well be that people separate between trust in the institution police and in the work of police officers. Moreover, there is no "Swiss police" as such; due to federalist structures in Switzerland, each canton has its own police corps. Hence, even though the described results indicate a certain direction, in order to reach a better fundament for statements, further studies considering local aspects are necessary. 


\section{REFERENCES}

Bänziger, M. (2014). Innovative Polizeiansätze. Eine kritische Begutachtung verschiedener Strategien und deren Implementierung in der Schweiz. Thèse de doctorat, Faculté de droit et des sciences criminelles, Université de Lausanne.

Beetham, D. (1991). The legitimation of power. Atlantic Highlands, N.J.: Humanities Press International.

Bradford, B., Jackson, J., \& Stanko, E. A. (2009). Contact and confidence: revisiting the impact of public encounters with the police. Policing and Society, 19(1), 20-46.

Bradford, B. (2014). Policing and social identity: procedural justice, inclusion and cooperation between police and public. Policing and Society, 24(1), 1-22.

Brodeur, J.-P. (2008). Les organisations policières en Europe continentale de l'Ouest. In M. Cusson, B. Dupont, \& F. Lemieux Traité de sécurité intérieure (pp. 81-88). Lausanne: Presses polytechniques et universitaires romandes.

Contrainfo (2015). Gegen die Stadt der Reichen. Retrieved from http://de.contrainfo.espiv.net/2015/02/15/gegen-die-stadt-der-reichen-pdf/. Accessed on November 27, 2015.

Corruption Perceptions Index (2014). Transparency International. Retrieved from http://www.transparency.org/cpi2014. Accessed on November 25, 2014.

European Social Survey ESS5 (2010). Appendix A6: Variables and Questions. Retrieved from http://www.europeansocialsurvey.org/docs/round5/survey/ESS5_appendix_a6_e03_0.pdf Accessed on November 24, 2015.

Gau, J. M. (2010). A longitudinal analysis of citizens' attitudes about police. Policing: An International Journal of Police Strategies \& Management, 33(2), 236-252.

Gyr, M. (2013). Jugendkriminalität: Eine "Night-Police" gegen Nachtstadtdelikte. Neue Züricher Zeitung, March 28, 2013. Retrieved from http://www.nzz.ch/zuerich/eine-nightpolice-gegen-nachtstadt-delikte-1.18054849. Accessed on November 24, 2015.

Hardin, R. (2002). Trust and trustworthiness. New York: Russell Sage Foundation.

Hough, M., Jackson, J., Bradford, B., Myhill, A., \& Quinton, P. (2010). Procedural Justice, Trust, and Institutional Legitimacy. Policing, 4(3), 203-210.

Jackson, J., \& Bradford, B. (2010). What is Trust and Confidence in the Police? Policing, $4(3), 241-248$.

Jackson, J., Bradford, B., Stanko, B., \& Hohl, K. (2012a). Just authority: Trust in the police in England and Wales. New York, NY: Routledge.

Jackson, J., Bradford, B., Hough, M., Myhill, A., Quinton, P., \& Tyler, T. R. (2012b). Why do people comply with the law? Legitimacy and the influence of legal institutions. British Journal of Criminology, 52, 1051-1071. 
Jackson, J., Bradford, B., MacQueen, S., \& Hough, M. (2015). Truly Free Consent? On the Nature of Duty to Obey. June 18, 2015. Retrieved from http://ssrn.com/abstract=2620274 Accessed on November 24, 2015.

Jeker, R. (2005). Welche Sicherheit brauchen Städte und Kommunen aus Sicht des Kantons? In Konferenz der Städtischen Polizeidirektorinnen und Polizeidirektoren und Stadt Zürich Vol. 2. KSPD, Community policing - Modelle für eine vernetzte Polizeiarbeit in der Schweiz. Referate der Tagung vom 10. September 2004 (pp. 1-7). Zürich: Schulthess.

Meyer, M. (2012a). La force publique devant les caméras. Considérations sur la sousveillance de la police par ses publics. format magazine, 3, 8-11.

Meyer, M. (2012b). The Viewer and the Viewed. Circulating Images of the Police, Between Professionals, the Mass Media and the Public. Penal Issues, 12, 1-4.

Schmid, A. (2015). Mehr Taser-Einsätze denn je im Jahr 2014. NZZ am Sonntag, January 12, 2015, 12 .

Schmoll, G. (1990). Geschichte der Schweizer Polizei: Band 1: Ursprünge und Traditionen. Muttenz: Verlag Bürger und Polizei.

Reisig, M. D., \& Chandek, M. S. (2001). The effects of expectancy disconfirmation on outcome satisfaction in police-citizen encounters. Policing: An International Journal of Police Strategies \& Management, 24(1), 88-99.

Skogan, W. G. (2005). Citizen Satisfaction with Police Encounter. Police Quarterly, 8(3), 298-321.

Staubli, S. (2015). Trust in and Attitudes towards the Police: Empirical Analyses for Europe with a Special Focus on Switzerland. Doctoral thesis. Zurich: University of Zurich.

Sunshine, J., \& Tyler, T. R. (2003). The Role of Procedural Justice and Legitimacy in Shaping Public Support for Policing. Law \& Society Review, 37(3), 513-548.

Szvircsev Tresch, T., \& Wenger, A. (Eds.) (2015). Sicherheit 2015: Aussen-, Sicherheits- und Verteidigungspolitische Meinungsbildung im Trend. Zürich: ETH Zürich: Center Security Studies und Militärakademie.

Tages Anzeiger (2015). Polizisten feuerten 2014 nur elfmal ihre Waffe ab. Retrieved from http://www.tagesanzeiger.ch/schweiz/standard/Polizisten-feuerten-2014-nur-elfmal-ihreWaffe-ab/story/15820628. Accessed on November 24, 2015.

Tankebe, J. (2013). Viewing things differently: The dimensions of public perceptions of legitimacy. Criminology, 51(1), 103-135.

Tyler, T. R. (2009). Legitimacy and Criminal Justice: The Benefits of Self-Regulation. Ohio State Journal of Criminal Law, 7, 309-359.

Tyler, T. R. (2006). Why people obey the law. New Haven: Yale University Press.

Tyler, T. R. (1998). Trust and Democratic Governance: In V. A. Braithwaite \& M. Levi Trust and governance (pp. 269-294). New York: Russell Sage Foundation. 
Tyler, T. R., \& Huo, Y. J. (2002). Trust in the law: Encouraging public cooperation with the police and courts. New York: Russell Sage Foundation.

Raval, C. (2015). Gewalt gegen Polizisten und Polizistinnen. Betroffene über das Erleben von Gewalt im Polizeilichen Berufsalltag und den Umgang damit. Master thesis. Universität Fribourg.

Van Maanen, J. (2003). Comment devient-on policier? In J.-P. Brodeur, \& D. Monjardet Connaître la Police. Grands textes de la recherche anglo-saxonne (pp. 125-154). Paris: La Documentation française.

Weber, M. (1980). Wirtschaft und Gesellschaft: Grundriss der verstehenden Soziologie. Tübingen: Mohr.

Wu, Y., \& Sun, I. Y. (2009). Citizen Trust in Police: The Case of China. Police Quarterly, 12(2), 170-191. 


\begin{tabular}{|c|c|c|c|c|c|c|c|c|c|c|}
\hline & $\begin{array}{c}\text { Moral } \\
\text { alignment }\end{array}$ & $\begin{array}{l}\text { Obligation } \\
\text { to obey }\end{array}$ & $\begin{array}{l}\text { Influence } \\
\text { of political } \\
\text { pressure }\end{array}$ & $\begin{array}{l}\text { How often } \\
\text { do police } \\
\text { take bribes }\end{array}$ & $\begin{array}{l}\text { Procedural } \\
\text { Fairness }\end{array}$ & $\begin{array}{l}\text { Personal } \\
\text { morality }\end{array}$ & $\begin{array}{c}\text { Risk of } \\
\text { sanctions }\end{array}$ & $\begin{array}{l}\text { All laws } \\
\text { should be } \\
\text { strictly } \\
\text { obeyed }\end{array}$ & $\begin{array}{l}\text { Doing the } \\
\text { right thing } \\
\text { sometimes } \\
\text { means } \\
\text { breaking } \\
\text { the law }\end{array}$ & Age \\
\hline Moral alignment & 1 & $.089^{* *}$ & $-.123^{* * * *}$ & $-.297^{* \cdots * *}$ & $.474^{* * *}$ & $.176^{* * * *}$ & .009 & $.251^{* * * *}$ & $-.128^{* * * *}$ & $.157^{* * *}$ \\
\hline Obligation to obey & $.089^{* * * *}$ & 1 & $-.065^{*}$ & $-.106^{* * *}$ & $.106^{* * *}$ & .018 & .051 & $.175^{* * *}$ & $-.146^{* * *}$ & $-.054^{*}$ \\
\hline Influence of political pressure & $-.123^{* * *}$ & $-.065^{*}$ & 1 & $.245^{* * *}$ & $-.142^{* * *}$ & .031 & .013 & -.050 & $.129^{* * *}$ & .020 \\
\hline How often do police take bribes & $-.297^{* * *}$ & $-.106^{* * *}$ & $.245^{* * *}$ & 1 & $-.271^{* * *}$ & $-.064^{*}$ & .022 & $-.127^{* * *}$ & $.166^{* * * *}$ & -.023 \\
\hline Procedural Fairness & $.474^{* * * *}$ & $.106^{* * * *}$ & $-.142^{* * * *}$ & $-.271^{* * *}$ & 1 & $.145^{* * *}$ & -.015 & $.203^{* * *}$ & $-.163^{* * *}$ & $.090^{* *}$ \\
\hline Personal morality & $.176^{* * * *}$ & .018 & .031 & $-.064^{*}$ & $.145^{* * *}$ & 1 & $.159^{* *}$ & $.218^{* * *}$ & $-.087^{* *}$ & $.241^{* *}$ \\
\hline Risk of sanctions & .009 & .051 & .013 & .022 & -.015 & $.159^{* * *}$ & 1 & $.098^{* * *}$ & -.031 & .033 \\
\hline $\begin{array}{l}\text { All laws should be strictly } \\
\text { obeyed }\end{array}$ & $.251^{* *}$ & $.175^{* *}$ & -.050 & $-.127^{* *}$ & $.203^{* *}$ & $.218^{* *}$ & $.098^{* *}$ & 1 & .020 & .033 \\
\hline $\begin{array}{l}\text { Doing the right thing sometimes } \\
\text { means breaking the law }\end{array}$ & $-.128^{* *}$ & $-.146^{* *}$ & $.129^{* *}$ & $.166^{* *}$ & $-.163^{* *}$ & $-.087^{* *}$ & -.031 & $.053^{*}$ & 1 & $-.286^{* *}$ \\
\hline Age & $.157^{* *}$ & $-.054^{*}$ & .020 & -.023 & $.090^{* *}$ & $.241^{* * * *}$ & .033 & .033 & $.053^{*}$ & 1 \\
\hline
\end{tabular}

*** Correlation is significant at the 0.001 level

** Correlation is significant at the 0.01 level

* Correlation is significant at the 0.05 level 


\section{ENDNOTES}

\footnotetext{
${ }^{1}$ Meanwhile, in January 2015, the responsible commission rejected the petition. The commission stated that they recognize the problem of increasing violence towards officials, but argued that other existing petitions better deal with the problem.
} 